\title{
The Capability of Neonatal Leukocytes to Produce IL-6 on Stimulation Assessed by Whole Blood Culture
}

\author{
AKIHIRO YACHIE, NOBUHIKO TAKANO, TOHRU YOKOI, KIMITAKA KATO, \\ YOSHIHITO KASAHARA, TOSHIO MIYAWAKI, AND NOBORU TANIGUCHI \\ Department of Pediatrics, School of Medicine, Kanazawa University, Kanazawa, Ishikawa 920, Japan
}

\begin{abstract}
IL-6 is a cytokine with a wide variety of influences on the cells involved in immune and inflammatory responses. Defective production of IL-6 may be partly responsible for the impaired immune defense and inflammatory response often observed in the neonatal period. In our study, we used whole blood culture to examine the capacity of neonatal leukocytes to produce IL-6 in response to various stimuli. IL-6 activity was evaluated by growth promoting assay using an IL-6-dependent murine hybridoma clone. IL-6 activity was undetectable in fresh or unstimulated blood obtained from both newborns and adults. In contrast, incubation of whole blood with lipopolysaccharide or concanavalin A resulted in marked IL-6 activity. After stimulation, IL-6 activity was induced as early as $\mathbf{2} \mathrm{h}$ after culture and increased with time, reaching a plateau at around $12 \mathrm{~h}$. Comparative examinations suggested that the IL-6 activity induced in neonatal blood on stimulation was similar to that seen in stimulated adult blood. Neutralization experiments with anti-IL-6 antiserum confirmed the presence of IL-6 proteins in the stimulated blood, and induction of cellular IL-6 mRNA was demonstrated in the stimulated blood as well. In addition, immunocytochemical observations suggested that the major IL-6 producing cells in the stimulated blood may be monocytes. The results suggest that the production of IL-6 in response to specified stimuli is normal at birth. (Pediatr Res 27: 227-233, 1990)
\end{abstract}

\section{Abbreviations}

MNC, mononuclear cell

LPS, lipopolysaccharide

Con A, concanavalin A

APP, acute phase proteins

BSF-2, B cell stimulatory factor 2

Hepes, $N$-2-hydroxyethylpiperazine- $\mathrm{N}^{\prime}$-2-ethanesulfonic acid

MTT, 3-(4,5-dimethylthiazol-2-yl)2,5-diphenyltetrazolium bromide

TBS, Tris buffered saline

TNF, tumor necrosis factor

IL-6 was first identified as T cell-derived BSF-2 that causes the terminal differentiation of $\mathbf{B}$ cells into Ig-producing cells (1).

Received July 21, 1989; accepted November 8, 1989

Correspondence and requests for reprints Akihiro Yachie, M.D., Department of Pediatrics, School of Medicine, Kanazawa University, 13-1 Takara-machi, Kanazawa, Ishikawa 920, Japan.

Supported by grants from the Ministry of Education, the Ministry of Welfare in Japan, Mother-and-Child's Health Foundation, and Uehara Memorial Foundation.
After cDNA for BSF-2 was cloned, the molecule was found to be identical to $26-\mathrm{kD}$ protein, IFN $-\beta_{2}$, and hybridoma growth factor, all of which had been described previously (2). It has been established that IL-6 has many biologic functions, which participate in the growth and differentiation of B cells, T cells, myeloma-plasmacytoma and hematopoietic cells (3-6). Recently, Gauldie et al. (7) have shown that IL-6 is functionally and immunologically identical to hepatocyte stimulating factor that can elicit the de novo production of APP by hepatocytes. Using recombinant preparations of IL- 6 , its induction of hepatocytederived APP has been demonstrated in vivo (8) as well as in vitro (9). Additionally, IL-6 appears to play an important role in mediating the pyrogenic response to tissue damage (10). Increased serum levels of IL-6 activity have been observed in patients with febrile illnesses such as bacterial and viral infections and autoimmune disorders $(11,12)$. Extremely high titers of IL6 have been found in body fluids, such as cerebrospinal fluids, urine and synovial fluids, obtained from various disease conditions (13-15). Thus, IL-6 has now emerged as a major component mediating the host response to inflammatory stimuli such as infection and tissue damage.

The neonatal immune system is relatively immature compared to that of the adult, with significant differences present with regard to the Ig-producing ability of $B$ cells and regulation of $B$ cell differentiation by $T$ cells $(16,17)$. In addition, the neonatal period is characterized by a diminished febrile response during bacterial infections (18). This diminished febrile response of newborn babies has been, in part, attributed to the deficient production of endogenous pyrogens or decreased hypothalamic thermoregulator sensitivity to pyrogens $(19,20)$. The limited production of IL- 6 in response to many pathogens may be partly responsible for the inadequate febrile response and lymphocyte dysfunction in the neonatal period. In our work, we used the culture method using whole blood, in an attempt to mimick in vivo conditions, to examine whether the ability to produce IL-6 in response to various stimuli is well developed at birth or not.

\section{MATERIALS AND METHODS}

Samples. Heparinized venous blood was obtained from healthy adult volunteers aged 25 to $35 \mathrm{y}$. Neonatal cord blood samples were collected from the placental end of the umbilical cord immediately after the birth of full-term newborn babies. The MNC were separated freshly or after culture from the whole blood by Ficoll-Hypaque gradient centrifugation after dextran sedimentation (21).

$I L-6$ induction in vitro. The whole blood cultures were prepared in polypropylene tubes (Falcon no. 2005; Becton Dickinson and Co., Lincoln Park, $\mathrm{NJ}$ ) at $37^{\circ} \mathrm{C}$ in a humidified atmosphere of $5 \% \mathrm{CO}_{2}$ in air. Two milliliters of whole blood were incubated for $12 \mathrm{~h}$ with various concentrations of LPS $(0.01$ to $10 \mu \mathrm{g} / \mathrm{mL}$ ) (lot. no. 026:B6; Difco Laboratories, Detroit, MI) or 
Con A $(0.08$ to $50 \mu \mathrm{g} / \mathrm{mL}$ ) (Difco). For the kinetics study, the whole blood was cultured with $1 \mu \mathrm{g} / \mathrm{mL}$ LPS or $10 \mu \mathrm{g} / \mathrm{mL}$ Con A for various time periods up to $48 \mathrm{~h}$. Unless otherwise indicated, the whole blood cultures were carried out for $12 \mathrm{~h}$ in the presence or absence of $1 \mu \mathrm{g} / \mathrm{mL}$ LPS or $10 \mu \mathrm{g} / \mathrm{mL}$ Con $\mathrm{A}$. In some experiments, the whole blood was stimulated with a streptococcal preparation, OK432 $(10 \mu \mathrm{g} / \mathrm{mL}$ ) (Chugai Pharmaceuticals, Tokyo, Japan). After culture, the plasma was separated from the cultured blood by centrifugation at $500 \times g$ for $10 \mathrm{~min}$, heatinactivated at $56^{\circ} \mathrm{C}$ for $30 \mathrm{~min}$, filtered through $0.45 \mu \mathrm{m}$ millipore filters, and provided for IL- 6 assay as described below.

Freshly isolated MNC were suspended at $1 \times 10^{6}$ cells $/ \mathrm{mL}$ in RPMI 1640 medium supplemented with $25 \mathrm{mM}$ Hepes, $0.3 \mathrm{mg} /$ $\mathrm{mL}$ L-glutamine, $200 \mathrm{U} / \mathrm{mL}$ penicillin, and $10 \mu \mathrm{g} / \mathrm{mL}$ gentamicin. The cells were incubated in polypropylene tubes with or without LPS or Con A for $12 \mathrm{~h}$ at $5 \% \mathrm{CO}_{2}$ in air. Two different sources of FCS (Mitsubishi Chemical Industries Ltd., Tokyo, Japan and M. A. Bioproducts, Walkersville, MD) were added to some of the cell cultures. It was confirmed by a standard assay using the Limulus test that these FCS preparations and Con A contained less than $50 \mathrm{pg} / \mathrm{mL}$ endotoxin.

$I L-6$ assay. IL-6 activity in the plasma from cultured blood or supernatants from MNC cultures was evaluated by a colorimetric assay using a murine IL-6-dependent hybridoma clone, MH60.BSF2 (provided by Drs. T. Hirano and T. Kishimoto, Osaka University, Osaka, Japan) $(11,22)$. The hybridoma cells were maintained in the presence of human rIL-6 (provided by Drs. T. Hirano and T. Kishimoto) in RPMI 1640 medium containing 10\% FCS (Gibco, Grand Island, NY), 25 mM Hepes, $0.3 \mathrm{mg} / \mathrm{mL}$ L-glutamine, $200 \mathrm{U} / \mathrm{mL}$ penicillin, $10 \mu \mathrm{g} / \mathrm{mL}$ gentamicin, and $60 \mu \mathrm{g} / \mathrm{mL}$ tylocine (assay medium). The cells at logarithmic growth were washed three times in assay medium and preincubated for $6 \mathrm{~h}$ without IL- 6 at $37^{\circ} \mathrm{C}$ in an attempt to remove the cell-bound IL-6. After this starvation period, the cells were spun down and resuspended in the assay medium. These cells $\left(10^{4}\right)$ were added to 96 -well flat bottom microtiter plates (Corning Glass Works, Corning, NY) at a volume of $0.1 \mathrm{~mL} /$ well. Serial dilutions of the samples $(100 \mu \mathrm{L})$ were added to each well. The cells were cultured for $48 \mathrm{~h}$ at $37^{\circ} \mathrm{C}$ in a humidified atmosphere of $5 \% \mathrm{CO}_{2}$ in air. After $44 \mathrm{~h}$ of culture, MTT (Sigma Chemical Co., St. Louis, MO) was freshly prepared, and added to each well at a concentration of $0.5 \mathrm{mg} / \mathrm{mL}$. After further incubation for $4 \mathrm{~h}$ at $37^{\circ} \mathrm{C}$, the plates were spun down at $200 \times$ $g$ for $5 \mathrm{~min}$. The supernatants were discarded by inverting the plates, and the excess dye and the medium was removed by paper towels. Acidified propylalcohol $(0.04 \mathrm{~N} \mathrm{HCl}$ in isopropanol) was added to each well $(100 \mu \mathrm{L} /$ well $)$. After leaving the plates for $20 \mathrm{~min}$ at room temperature, the contents were gently mixed by a plate mixer. A detergent solution ( $3 \%$ SDS in $\mathrm{H}_{2} \mathrm{O}$ ) was added to each well $(20 \mu \mathrm{L} /$ well $)$ to prevent the interference of the optical measurement by protein precipitates induced by the alcohol. The OD of the MTT formazan was read at $550 \mathrm{~nm}$ by an automatic microplate sepctrophotometer. The IL- 6 activities were calculated using a standard curve obtained for rIL-6. Human rIL-6 used in this work had a specific activity of $5.2 \times$ $10^{6} \mathrm{U} / \mathrm{mg}$ of protein determined by the augmentation of IgM secretion by a EBV-transformed cell line, SKW-CL14.

Neutralization of IL-6 activity by anti-IL-6 antiserum. The specificity of IL- 6 activity found in the plasma from cultured blood was confirmed by the neutralization experiments using a rabbit antiserum raised against rIL-6 (a gift from Drs. T. Hirano and $\mathrm{T}$. Kishimoto). The samples were mixed with various concentration of the antiserum or the nonimmune rabbit serum and incubated at $37^{\circ} \mathrm{C}$ for $1 \mathrm{~h}$, after which the neutralized samples were provided for IL-6 assay as above. Recombinant IL-6 preparation $(1 \mathrm{U} / \mathrm{mL})$ was used as a control.

Immunocytochemical staining of IL-6-producing cells. The cells with cytoplasmic IL-6 proteins were examined by the immunocytochemical method using the rabbit anti-rIL-6 antiserum (kindly provided by Dr. L. T. May, Rockefeller University) (23).
The cytocentrifuged preparations of MNC isolated from cultured blood were stained for cytoplasmic IL-6 immunocytochemically in the following procedure. The slides were fixed in $5 \%$ acetic acid and $95 \%$ ethanol for $30 \mathrm{~min}$ at $-20^{\circ} \mathrm{C}$. They were then washed three times in $0.05 \mathrm{M}$ TBS pH 7.6 and stained with the anti-IL-6 antiserum diluted at 1:100 in TBS for $60 \mathrm{~min}$. The control slides were stained with normal rabbit serum diluted at $1: 100$ in TBS. Subsequently, they were incubated with $1: 20$ dilution of alkaline phosphatase-conjugated goat anti-rabbit IgG (Tago Inc., Burlingame, CA) for $30 \mathrm{~min}$, and next with 1:40 dilution of alkaline phosphatase-conjugated swine anti-goat IgG (Tago) for $30 \mathrm{~min}$. All reactions were performed at room temperature. Each step was followed by three 3-min washes in TBS. They were finally stained by incubation in the alkaline phosphatase substrate solution containing naphtol AS-MX and Fast Red TR salt (Sigma) (24). This substrate contained $1 \mathrm{mM}$ levamizole to block endogenous neutrophil alkaline phosphatase activity. After 10 to $20 \mathrm{~min}$, the reactions were terminated by rinsing the slides in distilled water. The slides were counterstained with Carrazi's hematoxylin and mounted in glycerol gelatin.

RNA dot blot hybridization. The cytoplasmic RNA was isolated by the method of Chomczynski and Sacchi (25). The RNA was denatured with $2.2 \mathrm{M}$ formaldehyde, $50 \%$ formamide, 0.04 M 4-morpholine propane sulfonic acid, $10 \mathrm{mM}$ sodium acetate, $1 \mathrm{mM}$ EDTA at $65^{\circ} \mathrm{C}$ for $15 \mathrm{~min}$. For dot blot analysis, each aliquot of $5 \mu \mathrm{g} / \mathrm{mL}$ RNA and its 2-fold dilutions were blotted onto nylon membrane filters using a BIO-DOT apparatus (BioRad Lab., Richmond, CA) as recommended by the manufacturer. These filters were air-dried and baked at $80^{\circ} \mathrm{C}$ for $1 \mathrm{~h}$, prehybridized in $50 \%$ formamide, $5 \times$ SCC, $5 \times$ Denhardt's solution, $50 \mathrm{mM} \mathrm{NaPO}_{4}$, $\mathrm{pH} \mathrm{7.0,0.1 \%} \mathrm{SDS,} 0.2 \mathrm{mg} / \mathrm{mL}$ sheared salmon sperm DNA for $24 \mathrm{~h}$ at $42^{\circ} \mathrm{C}$. The hybridization buffer was the same as the prehybridization buffer except that it contained a $3 \times 10^{6} \mathrm{cpm} / \mathrm{mL}^{32} \mathrm{P}$-labeled probe. The TaqI-XbaI fragment of pBSF2.38.1 (IL-6 cDNA) (provided by Drs. T. Hirano and $T$. Kishimoto) was radiolabeled with a randomprimed DNA labeling system (Amersham International plc., Amersham, UK). The hybridization was carried out for $16 \mathrm{~h}$ at $65^{\circ} \mathrm{C}$ and the filters were exposed at $80^{\circ} \mathrm{C}$ for $48 \mathrm{~h}$ to $\mathrm{RX}$ x-ray film (Fuji Photo Film Co. Ltd., Kanagawa, Japan) with an intensifying screen.

\section{RESULTS}

Whole blood culture system for IL-6 induction. In our work, IL- 6 activity was evaluated by the ability of the samples to promote the growth of a murine IL-6-dependent hybridoma clone, MH60.BSF2. First, we investigated the appropriate culture conditions for IL- 6 induction by various stimuli. Table 1 shows

Table 1. IL-6 induction in different culture conditions on stimulation*

\begin{tabular}{ccccr}
\hline & \multicolumn{4}{c}{ IL-6 activity $(\mathrm{U} / \mathrm{mL})$} \\
\cline { 2 - 4 } & \multicolumn{3}{c}{ Separated MNC } \\
\cline { 2 - 5 } Stimulants & None & FCS I & FCS II & Whole blood \\
\hline None & $8.1(2.61) \dagger$ & $192.5(1.62) \ddagger$ & $62.3(1.46) \ddagger$ & $0.1(1.48)$ \\
LPS & $107.1(1.62)$ & $352.2(1.21)$ & $298.7(1.03)$ & $200.1(1.44)$ \\
Con A & $222.8(1.10) \ddagger$ & $275.9(1.32)$ & $304.2(1.50) \dagger$ & $63.0(1.07)$ \\
\hline
\end{tabular}

* Freshly isolated MNC from adult donors were suspended in culture medium with or without different FCS preparations. The whole blood or MNC were incubated either alone or with LPS $(1 \mu \mathrm{g} / \mathrm{mL})$ or Con A $(10 \mu \mathrm{g} / \mathrm{mL})$ for $12 \mathrm{~h}$ and the supernatants from the MNC cultures or the plasma from the whole blood cultures were examined for IL- 6 activity. The results represent the geometric means $\underset{x}{\dddot{x}}$ geometric SEM of three separate experiments; statistical significance was determined by $t$ test. Values were compared with whole blood data.

$\dagger p<0.05$.

$\ddagger p<0.001$. 
the results of IL- 6 induction in the cultures using isolated MNC or whole blood from the adult subjects. In all culture conditions, the cultures of MNC contained detectable levels of IL-6 activity $(10-200 \mathrm{U} / \mathrm{mL})$ even when cultured without stimulants. This spontaneous induction of IL- 6 activity in MNC cultures was marked when FCS was added to the culture. Although a relatively low activity of IL- 6 was induced in the serum-free medium $(8.1$ $\mathrm{U} / \mathrm{mL}$ ), the background responses seen in the MNC cultures made it difficult to evaluate the IL- 6 enhancement in response to appropriate stimuli. In distinct contrast to the $\mathrm{MNC}$ cultures, little IL-6 activity (less than $0.1 \mathrm{U} / \mathrm{mL}$ ) was induced when the whole blood was cultured for the same period of time. As shown in Table 1, the addition of LPS or Con A resulted in the induction of appreciable IL- 6 activity in the plasma of the cultured blood.

Figure 1 shows the kinetics of IL- 6 induction in LPS- or Con A-stimulated blood from an adult donor. When the whole blood was incubated with either LPS or Con A, IL-6 activity was detectable in the plasma as early as $2 \mathrm{~h}$ after stimulation, and increased with time, reaching a plateau at around $12 \mathrm{~h}$ after the culture. As shown in Figure 2, as little as $10 \mathrm{pg} / \mathrm{mL}$ of LPS could induce detectable levels of IL-6 activity in this system. Ten ng/ $\mathrm{mL}$ of LPS appeared to be sufficient to achieve maximum IL-6 induction in the cultured blood. However, in the Con A-stimulated blood, higher doses were required for maximum induction of IL-6 activity, which was less than that seen in the LPSstimulated cultures.

IL-6 production by stimulated neonatal cord blood and adult peripheral blood. Based on the preliminary experiments above, we here used the whole blood culture system to evaluate the capability of neonatal leukocytes to produce IL-6 in response to various stimuli. Neonatal cord blood and adult peripheral blood were incubated in the presence of LPS, Con A, or OK432, and the plasma from each stimulated blood sample was tested for IL6 activity. IL- 6 activity was undetectable in both the unstimulated neonatal blood and adult blood, but after any stimulation, IL-6 activity was detectable in the neonatal blood as well as adult blood at 2-4 h, and continued to increase thereafter, peaking at around $12 \mathrm{~h}$. The dose-responses of IL- 6 activity induced in the cord blood to different stimuli were similar to those in the adult blood (data not shown). Results from separate experiments from the cord blood and adult blood are summarized in Table 2. With respect to LPS and Con A stimulation, it should be noted that the IL-6 activity induced in neonatal blood was similar to that of adult subjects. Stimulation with OK432, a bacterial prepara- tion, seemed to induce somewhat higher levels of IL-6 activity in neonatal blood than in adult blood $(p<0.05)$.

To examine whether the MH60.BSF2 growth promoting activity induced in the LPS- or Con A-stimulated blood from the neonatal and adult samples was indeed due to the secretion of IL-6 molecules, neutralization experiments using rabbit anti-rIL6 antiserum were performed. As shown in Figure 3, the hybridoma clone growth promoting activity in the LPS-stimulated blood samples from newborns as well as adults was almost completely abolished by the rabbit anti-rIL- 6 serum, but not by normal rabbit serum. Similarly, IL-6 activity of Con A-stimulated blood was eliminated by anti-rIL-6 antibody (data not shown). We found that this hybridoma clone could proliferate in response to only rIL-6, but not to recombinant preparations of other cytokines such as IL-1, IL-2, IL-3, IL-4, interferons ( $\alpha$, $\beta, \gamma)$ and TNF. These observations confirmed that IL- 6 proteins can actually be induced in the plasma of neonatal blood and adult blood by LPS or Con A stimulation.

Expression of IL-6 MRNA in stimulated neonatal cord blood and adult peripheral blood. We next examined the expression of cellular IL-6 mRNA in stimulated blood. MNC were isolated from LPS-stimulated neonatal and adult blood, and analyzed for IL-6 mRNA content by the dot blot method. Cultures of freshly isolated $\mathrm{MNC}$ were also examined as controls for the expression of IL- 6 mRNA. As shown in Figure 4, no detectable IL-6 mRNA was induced in the whole blood cultures in the absence of stimuli, whereas measurable amounts of transcripts for IL-6 were present in unstimulated cultures of separated MNC. Incubation of the whole blood with LPS induced significant levels of IL-6 mRNA. Corresponding to the IL- 6 induction above, the expression of cellular IL-6 mRNA in the LPS-stimulated neonatal blood was similar to that of adult blood.

Immunocytochemical identification of IL-6 producing cells in stimulated blood. Using immunocytochemical technique to identify the cells producing IL- 6 protein in stimulated blood, MNC from the whole blood cultures, which had been incubated in the presence of LPS or Con A, were deposited on glass slides and fixed in 5\% acetic acid and $95 \%$ ethanol. Figure 5 represents a typical result obtained from neonatal blood. When the cells were stained by an immunoalkaline phosphatase method using rabbit anti-rIL-6 antiserum, intense granular staining was observed in a proportion of cells from the LPS- and Con A-stimulated blood. It was found that positive, but faint, staining appeared as early as $6 \mathrm{~h}$ after stimulation with LPS or Con A, and the cells with the most intense staining were found around 10 to $12 \mathrm{~h}$ after the
A

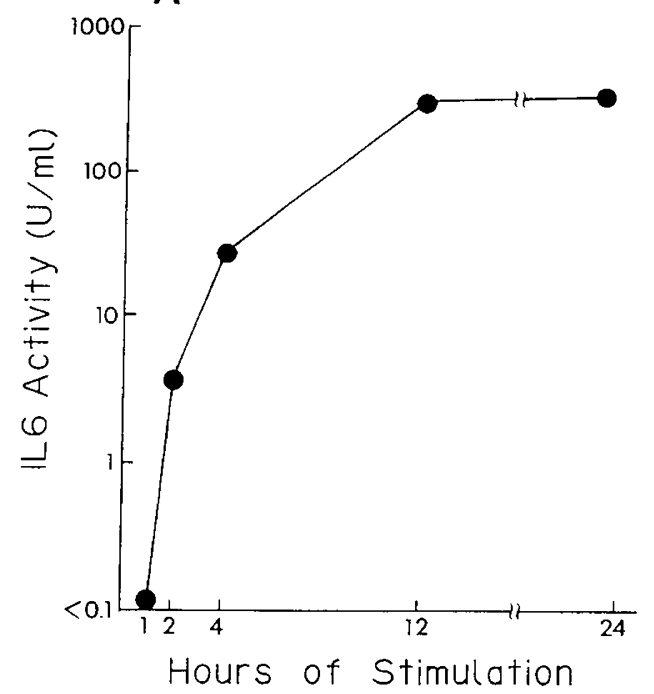

B

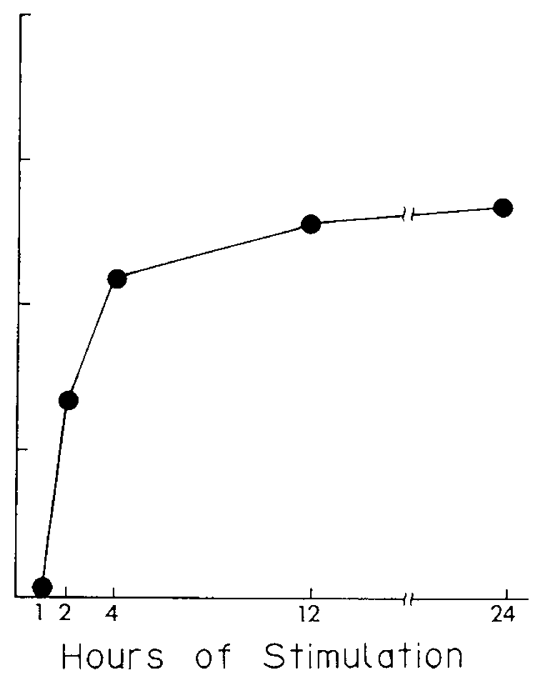

Fig. 1. Kinetics of induction of IL-6 activity in stimulated blood. Adult blood was stimulated with $1 \mu \mathrm{g} / \mathrm{mL}$ of LPS $(A)$ or $10 \mu \mathrm{g} / \mathrm{mL}$ of Con A $(B)$. The data represent the geometric means of five separate experiments. 

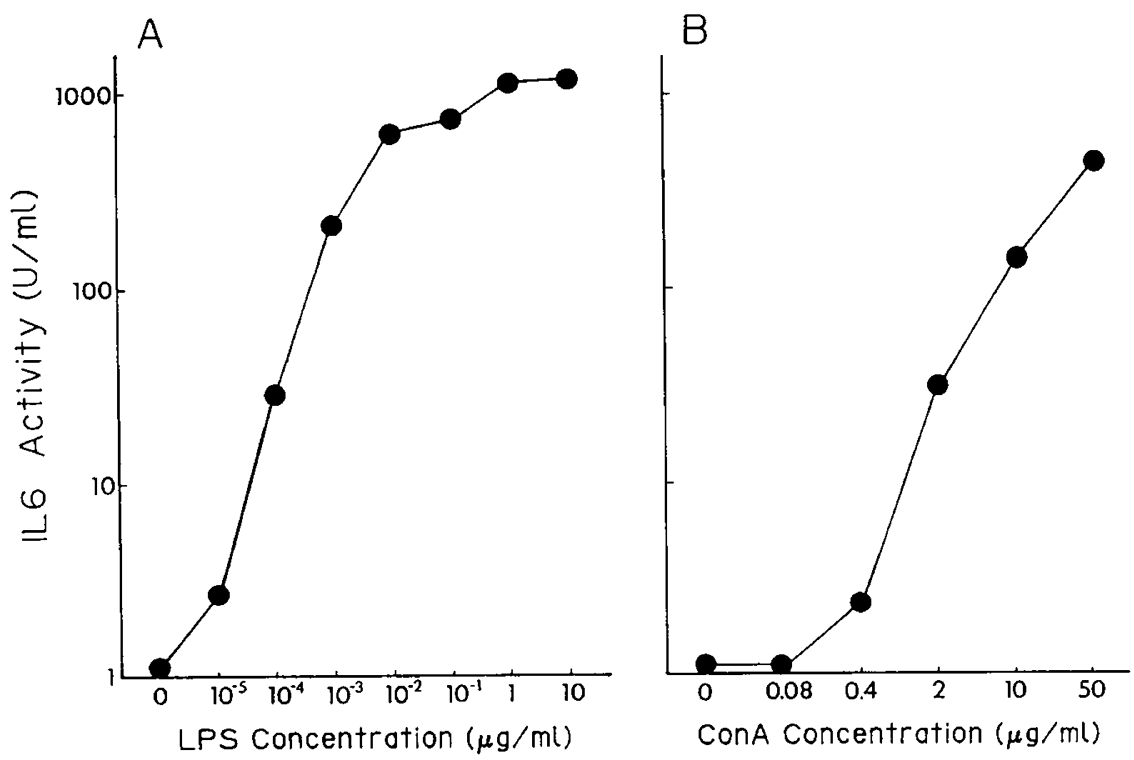

Fig. 2. Dose responses of IL-6 activity induction to LPS and Con A. Adult blood was stimulated with various doses of LPS $(A)$ or Con A $(B)$ for $12 \mathrm{~h}$. The data represent the geometric means of five separate experiments.

Table 2. Induction of IL-6 activity in neonatal cord blood and adult peripheral blood on stimulation*

\begin{tabular}{lcc}
\hline & \multicolumn{2}{c}{ IL-6 activity $(\mathrm{U} / \mathrm{mL})$} \\
\cline { 2 - 3 } \multicolumn{1}{c}{ Stimulants } & Neonate $(n=7)$ & Adult $(n=6)$ \\
\hline None & 0.1 & 0.1 \\
LPS $(1 \mu \mathrm{g} / \mathrm{mL})$ & $1193(1.17)$ & $1419(1.23)$ \\
Con A $(10 \mu \mathrm{g} / \mathrm{mL})$ & $217(1.18)$ & $176(1.49)$ \\
OK432 $(10 \mu \mathrm{g} / \mathrm{mL})$ & $228(1.08) \dagger$ & $51(1.69)$ \\
\hline
\end{tabular}

* Neonatal cord blood and adult peripheral blood were cultured for $12 \mathrm{~h}$ in the presence of various stimulants. The results represent the geometric means $\underset{+}{\times}$ geometric SEM; statistical significance was determined by $t$ test.

$\dagger$ Values significantly different from adult, $p<0.05$.

culture. Although the stained granules were usually seen throughout the cytoplasm, the most intense staining seemed to be localized in the Golgi area. In control experiments, there was no staining when nonimmune serum was substituted for the specific antiserum. As can be seen in Figure 5, these positive cells were larger in size than other small lymphocytes, and had horseshoelike nuclei with delicate nuclear chromatin, suggesting that they were morphologically monocytes. Only very few cells were stained by this technique in preparations from the unstimulated cultures. Essentially, adult cells stimulated with LPS or Con A were stained in the same manner as the neonatal cells. These results implied that monocytes might be the major cell type producing IL- 6 molecules on stimulation with Con A as well as LPS in the whole blood cultures.

\section{DISCUSSION}

We used a simple and reliable whole blood culture method to examine the IL- 6 production by neonatal leukocytes in response to various stimuli in comparison with that of adult ones. In the conventional culture method using isolated MNC, much IL-6 activity was observed in the culture supernatants even in the absence of added stimulants. This phenomenon may be related to some of the culture conditions, including the activation of
A

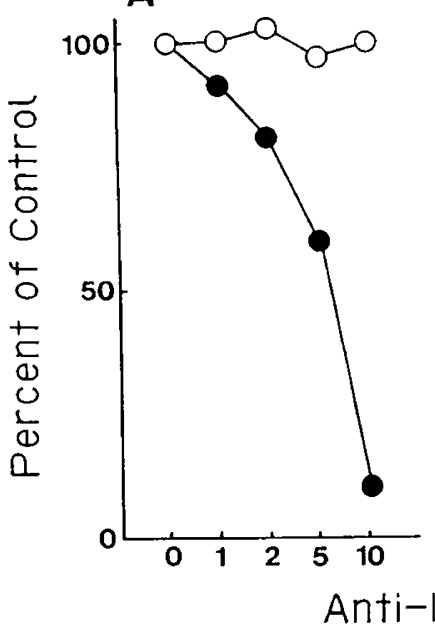

B

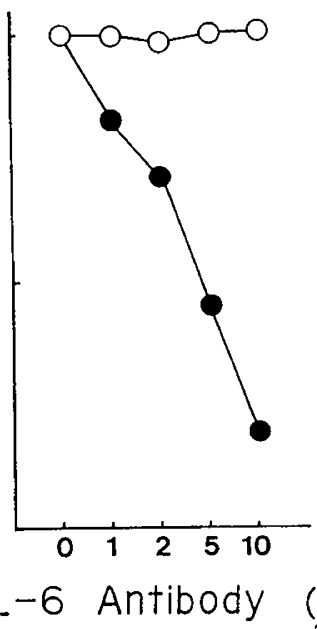

C

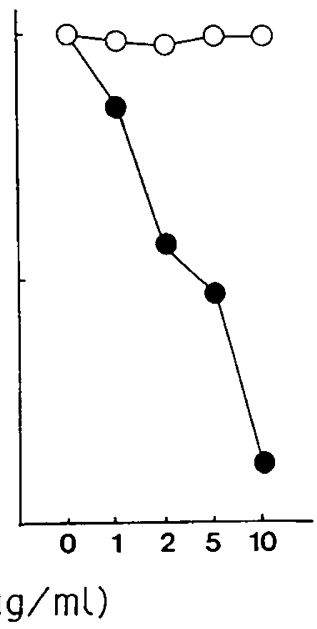

Fig. 3. Neutralization of IL-6 activity in the whole blood culture with anti-rIL-6 antiserum. Recombinant IL-6 $(A)$, neonatal blood $(B)$, and adult blood $(C)$ samples were incubated with various concentrations of rabbit anti-rIL-6 antiserum $(\bullet)$ or nonimmune serum $(O)$ at $37^{\circ} \mathrm{C}$ for $1 \mathrm{~h}$, and tested for IL-6 activity. 

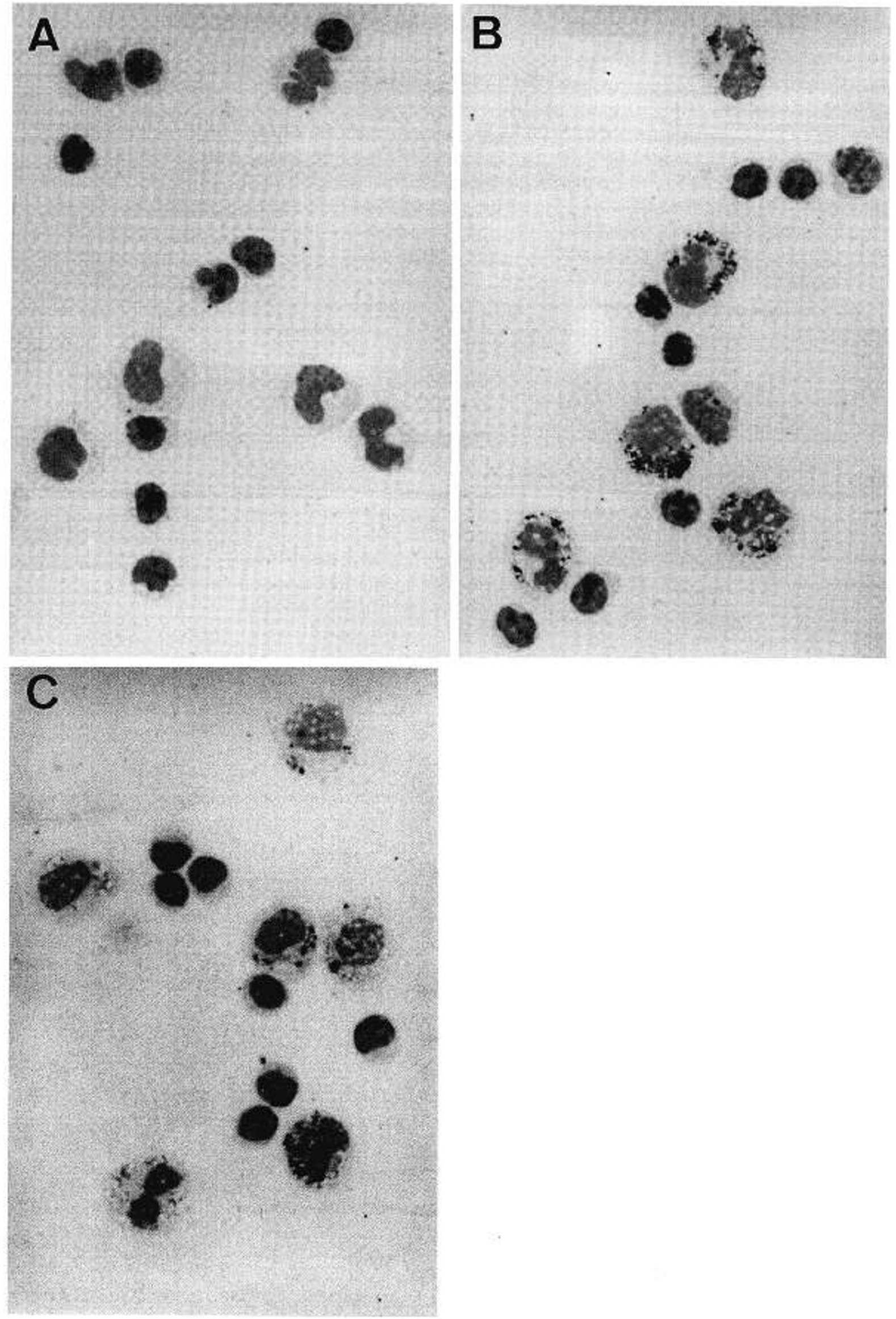

Fig. 4. Immunocytochemical detection of IL-6-containing cells in stimulated neonatal cord blood. MNC from neonatal blood, incubated either alone $(A)$ or with LPS $(B)$ or Con A $(C)$ for $12 \mathrm{~h}$, were deposited on glass slides, and stained for intracellular IL-6 proteins as described in Materials and Methods. 


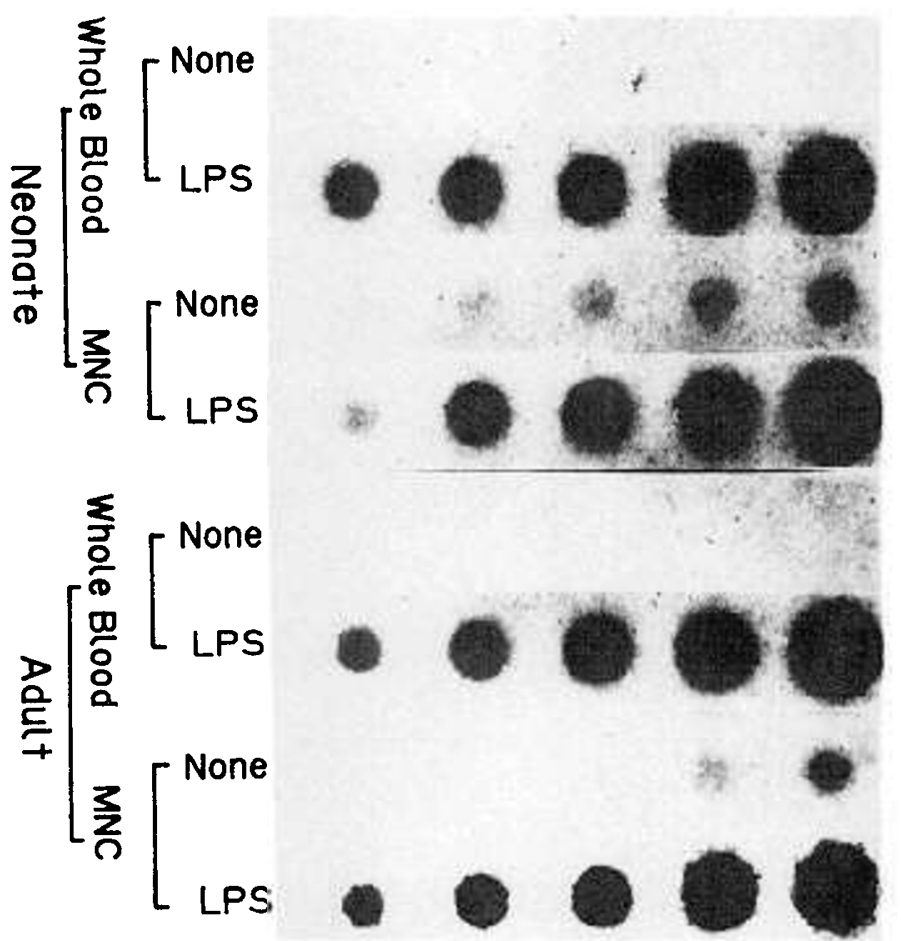

Fig. 5. Dot blot analysis for IL-6 mRNA. Total cytoplasmic RNA was obtained from $\mathrm{MNC}$ isolated from stimulated blood or cultured MNC, and hybridized with a random-primed cDNA probe for IL-6. Two-fold dilutions of $5 \mu \mathrm{g}$ of RNA were blotted.

cells due to their adherence to the plastic tubes and the presence of foreign proteins in the culture. It has been reported that the attachment of monocytes to the surfaces of culture instruments can induce the transcription of mRNA for IL-6 as well as TNF (26).

This adherence mechanism is likely responsible for, at least in part, the spontaneous production of IL- 6 activity in the cultures of MNC. Another possibility is contamination of the endotoxin in the FCS used for the culture medium. In fact, we encountered one lot of FCS containing a relatively large amount $(200 \mathrm{pg} / \mathrm{mL})$ of endotoxin. The use of this FCS resulted in the induction of a much higher level of IL-6 activity in the unstimulated cultures of isolated MNC, exceeding that of the stimulated cell cultures. We chose two lots of FCS containing less than $50 \mathrm{pg} / \mathrm{mL}$ of endotoxin to prepare the culture medium. Despite the use of these lots of FCS with less endotoxin, appreciable production of IL-6 activity was demonstrated in the cultures in the absence of stimuli, although spontaneous production of IL-6 activity was relatively modest in MNC cultures using FCS-free medium. In marked contrast, only a negligible amount of IL- 6 activity was detected in the whole blood cultured without stimuli, whereas induction of moderate IL-6 activity was demonstrable after stimulation with LPS or Con A. Therefore, the whole blood culture system could overcome the artificial cellular activation seen in the standard culture method with isolated MNC, and thus appeared to allow proper evaluation of de novo induction of IL-6 activity. The culture method using whole blood seemed to resemble closely in vivo situations such as those during bacterial and viral infections. Recently, Genord et al. (27) used whole blood for the assessment of TNF gene expression after LPS stimulation.

The impairment of defense mechanisms in the newborn is associated with increased susceptibility to microorganism invasion or an elevated risk of tissue damage due to activation of the inflammatory process (28). Because IL-6 plays a complex role in immune and inflammatory responses, we were interested to learn whether or not IL-6 production is fully developed at birth. Our data clearly indicate that neonatal leukocytes do not differ from adult ones in their ability to produce IL-6. When LPS or Con A was added to the neonatal blood, IL- 6 activity was induced at levels comparable to those of adult blood. The neutralization experiments with anti-rIL- 6 antiserum suggested that IL-6 activity found in the stimulated blood from both newborns and adults may reflect the secretion of true IL- 6 molecules. We observed that stimulation with a streptococcal preparation, OK432, resulted in slightly higher levels of IL-6 activity in the plasma of neonatal blood when compared to adult blood, although there was only small statistical significance in IL- 6 production between the two groups $(p<0.05)$.

The mechanisms by which IL- 6 production is controlled in the host and the cell types that secrete IL- 6 systemically or locally during infection or tissue damage remain to be elucidated. Recently, Jablons et al. (29) have demonstrated that in vivo administration of recombinant TNF results in the rapid appearance of IL- 6 in the peripheral blood. Furthermore, the induction of IL6 in the circulation has been found after injection of LPS (30). Although IL- 6 is produced by a variety of cells including fibroblasts, monocytes, $\mathrm{T}$ cells and vascular endothelial cells in vitro (1), the cellular origin of IL-6 observed after in vivo administration of TNF or LPS is unknown. We demonstrated by immunocytochemical analysis that the major IL-6-producing cells appear to be monocytes when whole blood from newborns as well as adults is cultured with LPS or Con A. In another study combining the use of in situ hybridization and the corresponding $\mathrm{MAb}$, we also confirmed that IL-6 is secreted largely by monocytes in the stimulated blood (31).

IL-1 and TNF are other monocyte-derived cytokines with multiple biologic activities, including immunologic effects, mediation of febrile responses, and acute phase response to infection. Consistent with our results, it has been reported that production of IL-1 by neonatal MNC is comparable to adult production (32). English et al. (33) have demonstrated that neonatal MNC produce substantial amounts of TNF in response to nonspecific stimuli such as PHA, although TNF production by neonatal MNC is somewhat less than production by adult cells. We demonstrated that the ability of monocytes to produce IL- 6 is mature at birth. Taken together, it is unlikely that the limited production of these products by monocytes contributes to the diminished febrile response, increased susceptibility to severe infections, or lymphocyte immaturity of the human neonate.

It is well known that the etiologic characteristics of bacterial infections in the newborn are quite different from those in the older infant (34). It has been shown that the capability of monocytes to phagocytose microorganisms is almost normal in fullterm newborns $(35,36)$. However, there is evidence that some monocyte functions are altered in the neonatal period, playing a role in the enhanced susceptibility to infectious agents. In particular, a lower expression of HLA-DR antigens, with an associated decrease of antigen presentation and of intracellular killing activity induced by some lymphokines, is noted (37-39). It remains to be determined whether the intracellular cytokine production process, such as that of IL-6 after phagocytosis of microorganisms, is impaired in neonatal monocytes. It is attractive to suppose that microorganism-mediated production of IL- 6 by neonatal monocytes may differ according to the kind of infectious agent. To resolve this question, production of IL-6 in neonatal blood when incubated with various strains of live bacteria is currently under investigation.

Acknowledgments. The authors thank Drs. T. Hirano and T. Kishimoto for kindly providing reagents and cells, and Dr. M. Ohshita (Seirei Hospital, Kanazawa) for the supply of cord blood samples. We are also grateful to Misses R. Miyazaki and Y. Tai for their excellent technical assistance. 


\section{REFERENCES}

1. Hirano T, Kishimoto T 1989 Interleukin-6 (IL-6). In: Sporn MB, Roberts AB (eds) Handbook of Experimental Pharmacology-Peptide Growth Factors and their Receptors. Springer-Verlag, Berlin (in press)

2. Hirano T, Yasukawa K, Harada H, Taga T, Watanabe Y, Matsuda T, Kashiwamura $S$, Nakajima $K$, Koyama K, Iwamatsu A, Tsunasawa S, Sakiyama F, Matsui H, Takahara Y, Taniguchi T, Kishimoto T 1986 Complementary DNA for a novel human interleukin (BSF2) that induces B lymphocytes to produce immunoglobulin. Nature 324:73-76

3. Tosato G, Seamon KB, Goldman ND, Sehgal PB, May LT, Washington GC Jones KD, Pike SE 1988 Monocyte-derived human B-cell growth factor as interferon- $\beta_{2}$ (BSF-2, IL-6). Science 239:502-504

4. Tosato G, Gerrard TL, Goldman ND, Pike SE 1988 Stimulation of EBVactivated human $B$ cells by monocytes and monocyte products. Role of IFN$\beta_{2} /$ B cell stimulatory factor 2/IL-6. J Immunol 140:4329-4336

5. Uyttenhove C, Coulie PG, Van Snick J 1988 T cell growth and differentiation induced by interleukin-HP1/IL-6, the murine hybridoma/plasmacytoma growth factor. J Exp Med 167:1417-1427

6. Wong GG, Witek-Giannotti JS, Temple PA, Kriz R, Ferenz C, Hewick RM, Clark SC, Ikebuchi K, Ogawa M 1988 Stimulation of murine hemopoietic colony formation by human IL-6. J Immunol 140:3040-3044

7. Gauldie J, Richards C, Harnish D, Lansdorp P, Baumann H 1987 Interferon $\beta_{2} /$ B-cell stimulatory factor type 2 shares identity with monocyte-derived hepatocyte-stimulating factor and regulates the major acute phase protein response in liver cells. Proc Natl Acad Sci USA 84:7251-7255

8. Geiger T, Andus T, Klapproth J, Hirano T, Kishimoto T, Heinrich PC 1988 Induction of rat acute-phase proteins by interleukin 6 in vivo. Eur J Immunol 18:717-721

9. Castell JV, Gomez-Lechon MJ, David M, Hirano T, Kishimoto T, Heinrich PC 1988 Recombinant human interleukin-6 (IL-6/BSF-2/HSF) regulates the synthesis of acute phase proteins in human hepatocytes. FEBS Lett 232:347-350

10. Nijsten MWN, De Groot ER, Ten Duis HJ, Klasen HJ, Hack CE, Aarden LA 1987 Serum levels of interleukin-6 and acute phase responses. Lancet 2:921

11. Ueno Y, Takano N, Kanegane H, Yokoi T, Yachie A, Miyawaki $T$, Taniguch N 1989 The acute phase nature of interleukin 6: studies in Kawasaki disease and other febrile illness. Clin Exp Immunol 76:337-342

12. Swaak AJG, Van Rooyen A, Aarden LA 1989 Interleukin-6 (IL-6) and acute phase proteins in the disease course of patients with systemic lupus erythematosus. Rheumatol Int 8:263-268

13. Helfgott DC, Tatter SB, Santhanam U, Clarick RH, Bhardwaj N, May LT Sehgal PB 1989 Multiple forms of IFN- $\beta_{2} /$ IL-6 in serum and body fluids during acute bacterial infection. J Immunol 142:948-953

14. Houssiau FA, Bukasa K, Sindic CJM, Van Damme J, Van Snick J 1988 Elevated levels of the $26 \mathrm{~K}$ human hybridoma growth factor (interleukin 6) in cerebrospinal fluid of patients with acute infection of the central nervous system. Clin Exp Immunol 71:320-323

15. Van Oers MHJ, Van der Heyden AA, Aarden LA 1988 Interleukin 6 (IL-6) in serum and urine of renal transplant recipients. Clin Exp Immunol 71:314319

16. Miyawaki T, Moriya N, Nagaoki T, Taniguchi N 1981 Maturation of B-cell differentiation ability and T-cell regulatory function in infancy and childhood. Immunol Rev 57:61-87.

17. Yachie A, Miyawaki T, Nagaoki T, Yokoi T, Mukai M, Uwadana N, Taniguchi N 1981 Regulation of $B$ cell differentiation by $\mathbf{T}$ cell subsets defined with monoclonal OKT4 and OKT8 antibodies in human cord blood. J Immunol 127:1314-1317

18. Bellanti JA, Boner AL, Valletta E 1987 Immunology of fetus and newborn. In: Avery GB (ed) Neonatology. JB Lippincott Co, Philadelphia, pp 850873
19. Blatteis CM 1975 Postnatal development of pyrogenic sensitivity in guinea pigs. J Appl Physiol 39:251-257

20. Blatteis CM 1976 Comparison of endotoxin and leukocyte pyrogen pyrogenecity in newborn guinea pigs. J Appl Physiol 42:355-361

21. Miyawaki T, Seki H, Kubo M, Taniguchi N 1979 Suppressor activity of T lymphocytes from infants assessed by co-culture with unfractioned adult lymphocytes in the pokeweed mitogen system. J Immunol 123:1092-1096

22. Matsuda T, Hirano T, Kishimoto T 1988 Establishment of an interleukin 6 (IL-6)/B cell stimulatory factor 2-dependent cell line and preparation of antiIL-6 monoclonal antibodies. Eur J Immunol 18:951-956

23. May LT, Ghrayeb J, Santhanam U, Tatter SB, Sthoeger Z, Helfgott DC, Chiorazzi N, Grieninger G, Sehgal PB 1988 Synthesis and secretion of multiple forms of $\beta_{2}$-interferon/B-cell differentiation factor $2 /$ hepatocytestimulatory factor by human fibroblasts and monocytes. J Biol Chem 263:7760-7766

24. Cordell JL, Falini B, Erber WN, Ghosh AK, Abdulaziz Z, MacDonald S, Pulford KAF, Stein H, Mason DY 1984 Immunoenzymatic labeling of monoclonal antibodies using immune complexes of alkaline phosphatase and monoclonal anti-alkaline phosphatase (APAAP complexes). J Histochem Cytochem 32:219-229

25. Chomczynski P, Sacchi N 1987 Single-step method of RNA isolation by acid guanidinium thiocyanate-phenol-chloroform extraction. Anal Biochem 162:156-159

26. Haskill S, Johnson C, Eierman D, Becker S, Warren K 1988 Adherence induces selective mRNA expression of monocyte mediators and protooncogenes. J Immunol 140:1690-1694

27. Genord M, Strieter R, Raiford C, Remick D, Lynch J, Kunkel S 1989 Assessment of the gene expression in whole blood and ex vivo kinetic analysis. The FASEB J 3:A821 (abstr)

28. Biondi A, Poli G, Parravicini, Molinari A, Mantovani A 1987 Mononuclear phagocyte function in the perinatal period. In: Burgio GR, Hanson LA, Ugazio AG (eds) Immunology of the Neonate. Springer-Verlag, Berlin, pp $59-66$

29. Jablons DM, Mule JJ, McIntosh JK, Sehgal PB, May LT, Huang CM, Rosenberg SA, Lotze MT 1989 IL-6/IFN- $\beta$-2 as a circulating hormone. Induction by cytokine administration in humans. J Immunol 142:1542-1547

30. Fong T, Moldwer LL, Marano M, Wei H, Tatter SB, Clarick RH, Santhanam U, Sherris D, May LT Sehgal PB, Lowry SF 1989 Endotoxemia elicits increased circulating $\beta_{2}$-IFN/IL-6 in man. J Immunol 142:2321-2324

31. Kato K, Yokoi T, Takano N, Kanegane H, Yachie A, Miyawaki T, Taniguchi N 1990 Detection by in situ hybridization and phenotypic characterization of cells expressing IL-6 mRNA in human stimulated blood. J Immunol (in press)

32. Wilmott RW, Harris MC, Haines KM, Douglas SD 1987 Interleukin-1 activity from human cord blood monocytes. Diagn Clin Immunol 5:201-204

33. English BK, Burchett SK, English JD, Ammann AJ, Wara DW, Wilson CB 1988 Production of lymphotoxin and tumor necrosis factor by human neonatal mononuclear cells. Pediatr Res 24:717-722

34. Bellanti JA, Hurtado RC 1976 Immunology and resistance to infection. In: Remington JA, Klein JO (eds) Infectious Diseases of the Fetus and Newborn Infant. WB Saunders, Philadelphia, p 33

35. Weston WL, Carson BS, Barkin RM, Slater GD, Dustin RD, Hecht SK 1977 Monocyte-macrophage function in the newborn. Am J Dis Child 131:12411242

36. Nakano K, Hosokawa T, Muramatsu S 1978 Ontogeny of macrophage function. I. Phagocytic activity and A-cell activity of newborn and adult mouse peritoneal macrophages. Dev Comp Immunol 2:505-518

37. Lu CY, Calamai EG, Unaue ER 1979 A defect in the antigen-presenting function of macrophages from neonatal mice. Nature 282:327-329

38. Kelley VE, Fiers W, Strom TB 1984 Cloned human interferon- $\gamma$, but not interferon- $\beta$ or $-\alpha$, induces expression of HLA-DR determinants by fetal monocytes and myeloid leukemic cell lines. J Immunol 132:240-245

39. Wilson CB, Haas JE 1984 Cellular defenses against Toxoplasma gondii in newborns. J Clin Invest 73:1606-1616 